\title{
Prevention and termination of pregnancy in rats by cabergoline, a dopamine agonist
}

\author{
H. Negishi ${ }^{1}$ and S. S. Koide ${ }^{2 *}$ \\ 'Department of Obstetrics and Gynecology, Hokkaido University, School of Medicine, Sapporo, Japan; \\ and ${ }^{2}$ Center for Biomedical Research. The Population Council, 1230 York Avenue, New York,
}

NY 10021, USA

\begin{abstract}
The objective of the study was to clarify the potency and action of cabergoline, a dopamine agonist, in preventing and terminating pregnancy in rats. Cabergoline administered s.c. to female rats on days 1, 2 and 3 of pregnancy prevented implantation of the fertilized ova and development of the embryos. The drug was $100 \%$ effective at doses of $10 \mathrm{\mu g} \mathrm{kg}^{-1}$ day $^{-1}$ or higher. Serum progesterone determined on day 8 of pregnancy was significantly reduced in rats treated with cabergoline at doses of $5 \mu \mathrm{g} \mathrm{kg}^{-1}$ day ${ }^{-1}$ and higher, whereas serum concentrations of oestradiol remained unchanged. Cabergoline at doses of 10 and $20 \mu \mathrm{g}$ $\mathrm{kg}^{-1}$ day ${ }^{-1}$ administered s.c. on days 7,8 and 9 of pregnancy was partially effective (43 and $50 \%$, respectively) in terminating pregnancy, whereas at doses of $30 \mathrm{\mu g} \mathrm{kg}^{-1}$ day ${ }^{-1}$, and higher, pregnancy was terminated in all treated rats. Serum concentrations of progesterone on days 12 and 16 of pregnancy were significantly lower in rats treated with doses of $10 \mu \mathrm{g} \mathrm{kg}^{-1}$ day $^{-1}$ or higher. Serum prolactin determined on day 4 of pregnancy in rats treated with cabergoline at the effective dose of $10 \mu \mathrm{g} \mathrm{kg}^{-1}$ day ${ }^{-1}$ on days 1,2 and 3 of pregnancy was significantly reduced to $1.7 \pm 0.62 \mathrm{ng} \mathrm{ml}^{-1}$ from a pretreatment value of $16.0 \mathrm{ng} \mathrm{ml}^{-1}$. The lowest effective dose of cabergoline in reducing serum prolactin determined on day 8 of pregnancy was $20 \mu \mathrm{g} \mathrm{kg}^{-1}$ day ${ }^{-1}$. The present results support the hypothesis that cabergoline acts by inhibiting prolactin production or release, thereby inhibiting progesterone biosynthesis by the ovary.
\end{abstract}

\section{Introduction}

High doses of ethynyloestradiol, diethystilboesterol and conjugated oestrogens are effective post-coital contraceptives (Fasoli et al., 1989). Other preparations include combined oestrogen-progestins, (ethynyloestradiol and dl-norgesterol), danazol and intrauterine devices. These drugs, however, induce severe side effects, such as nausea, emesis, breast tenderness and irregular bleeding. Anordrin, an antioestrogen, has been used as a morning-after pill in China with a failure rate of less than $0.5 \%$ (Shanghai Clinical Research Coordinating Group on Antifertility Tablet No. 53, 1977). The preferred medical treatment for terminating early pregnancy is the combination of mifepristone (RU 486), an antiprogestin, with misoprostol (an orally active PGE analog) (Silvestre et al., 1990; Avrech $e t$ al., 1991; Spitz and Bardin, 1993) or gemeprost (a $\mathrm{PGE}_{1}$ analog as vaginal pessary) (Peplow, 1994). Treatment with these drugs terminates pregnancy in $91-95 \%$ of users; however, objectionable side effects do occur including nausea, emesis, headaches and menstrual disturbances.

Cabergoline is a dopamine agonist used to treat hyperprolactinaemia in women (Rains ef al., 1995). It is well tolerated after prolonged use (Webster et al., 1994) and effectively

\footnotetext{
*Correspondence.
}

Received 3 July 1996. terminates pregnancy in species in which prolactin is an essential luteotrophic agent, for example rat, mice, dogs and cats (Di Salle et al., 1983a, b; Post et al., 1988, Jöckle and Jöckle, 1993; Onclin et al., 1993; Verstegen et al., 1993; Ferraro et al., 1995). The present study was performed to determine the potency of cabergoline in preventing and terminating pregnancy in rats and to clarify its mechanism of interference with the hormonal production required for implantation and development of embryos.

\section{Materials and Methods}

\section{Materials}

Cabergoline (1-[(6-allylergolin-8 $\beta$-yl)carbonyl]-I-[3-(dimethylamino)propyl]-3-ethylurea) was a gift of Pharmacia, Famitalia, Carlo Erba, Milan. Coat-A-Count ${ }^{k}$ progesterone and Coat-A Count ${ }^{18}$ oestradiol kits, a no extraction solid phase $\left[{ }^{125} \mathrm{I}\right]$ radioimmunoassay, were purchased from Diagnostic Products Corporation, Los Angeles, CA. The radioimmunoassay procedures described in the manufacture's manual were followed. The sensitivity of the assays was $0.03 \mathrm{ng} \mathrm{ml}^{-1}$ and $8 \mathrm{pg} \mathrm{ml}^{-1}$ for progesterone and oestradiol, respectively. The coefficients of variation of intra-assay and interassays were $2.6-6.4 \%$ and $5.1-10 \%$ for progesterone and $4-7 \%$ and 
4.2-8.1\% for oestradiol, respectively. Serum prolactin was determined according to Neil and Reichert (1971) using the rat PRL kit distributed by A. F. Parlow, Harbor Hospital-UCLA medical Center for NIDDK, NIH. The assay sensitivity for rPRL was $0.5 \mathrm{ng} \mathrm{ml}^{-1}$ and the coefficients of variation of intra-assay and interassay were $11-12 \%$ and $7.2 \%$, respectively.

\section{Animals and treatments}

Female rats (body mass: $180-220 \mathrm{~g}$ ) and male rats (body mass: $300-400 \mathrm{~g}$ ) of the Sprague-Dawley strain were purchased from Charles River Breeding Laboratories, Wilmington, MA. The rats were housed in a temperature-controlled (24.4$26.5^{\circ} \mathrm{C}$ ) and light-regulated ( $14 \mathrm{~h}$ light: $10 \mathrm{~h}$ dark) room and maintained on ad libitum sustenance of standard chow and water. Guidelines for the care and use of the animals approved by the Laboratory Animal Research Center, The Rockefeller, New York, were followed.

\section{Prevention of pregnancy}

Successful mating in female rats was verified by locating the presence of vaginal plugs or spermatozoa in the vagina $24 \mathrm{~h}$ after mating. This day was designated as day 1 of pregnancy. The potency of cabergoline in preventing pregnancy was determined by administering s.c. at doses ranging from 2.5 to $60 \mu \mathrm{g} \mathrm{kg}^{-1}$ day ${ }^{-1}$ to mated female rats on days 1,2 and 3 of pregnancy. The animals were killed on day 8 of pregnancy and uteri examined for implanted and developing embryos. Blood samples were collected on day 8 of pregnancy and serum analysed for progesterone and oestradiol by radioimmunoassay.

Ovaries were collected from control and mated rats treated on days 1,2 and 3 of pregnancy with cabergoline at doses of $2.5,5,10$ and $20 \mathrm{\mu g} \mathrm{kg}^{-1} \mathrm{day}^{-1}$. Tissues were fixed in Bouin's solution and sections prepared by Tissue Technique, Morristown, NJ. The sections were examined by Robert F. McConnell, D.V.M., Flemington, NJ.

\section{Termination of pregnancy}

The potency of cabergoline in terminating pregnancy was determined by administering the compound s.c. at doses ranging from 2.0 to $100 \mu \mathrm{g} \mathrm{kg}^{-1}$ day $^{-1}$ to pregnant rats on days 7,8 and 9 of pregnancy. The animals were killed on day 16 of pregnancy and uteri examined for developing embryos. Blood samples were collected on days 7 (pretreatment), 12 and 16 of pregnancy and sera assayed for progesterone and oestradiol.

\section{Effect of cabergoline on serum prolactin}

In the first experiment, the time course of cabergoline treatment on serum rPRL was determined by administering cabergoline s.c. at the effective dose of $10 \mu \mathrm{g} \mathrm{kg}^{-1}$ day ${ }^{-1}$. Blood was collected on days 4 and 6 of pregnancy and sera analysed for prolactin by radioimmunoassay. In the second experiment, the relative potencies of cabergoline in preventing
Table 1. Effect of cabergoline on early pregnancy in rats

\begin{tabular}{|c|c|c|c|c|c|}
\hline \multirow[b]{2}{*}{$\begin{array}{l}\text { Cabergoline } \\
\left(\mu \mathrm{gg}^{-1} \text { day }^{-1}\right)\end{array}$} & \multirow[b]{2}{*}{$n$} & \multicolumn{2}{|c|}{ Infertile rats } & \multicolumn{2}{|c|}{ Embryos in pregnant rats } \\
\hline & & Number & $\%$ & $\begin{array}{c}\text { Total } \\
\text { number }\end{array}$ & $\begin{array}{c}\text { Average number } \\
\text { per rat }\end{array}$ \\
\hline 0 & 10 & 1 & 10 & 140 & 15.6 \\
\hline 2.5 & 10 & 0 & 0 & 165 & 16.5 \\
\hline 5 & 9 & 7 & 67 & 34 & 11.3 \\
\hline 10 & 9 & 9 & 100 & 0 & - \\
\hline 20 & 10 & 10 & 100 & 0 & - \\
\hline 30 & 9 & 9 & 100 & 9 & - \\
\hline 60 & 10 & 10 & 100 & 0 & - \\
\hline
\end{tabular}

${ }^{a}$ Cabergoline was administered s.c. on days 1, 2 and 3 of pregnancy. Rats were killed on day 8 and uteri examined for embryos.

${ }^{b}$ Average number of embryos per pregnant rat.

pregnancy were determined. The drug was administered s.c. on days 1,2 and 3 of pregnancy and serum rPRL determined on day 8 of pregnancy.

\section{Statistical analyses}

Student's t test was used to compare the mean hormone concentrations between treated and control animals. Values were considered significant when $P<0.05$.

\section{Results}

\section{Prevention of pregnancy}

Cabergoline administered s.c. on days 1, 2 and 3 of pregnancy at doses of $10 \mu \mathrm{gg}^{-1}$ day $^{-1}$ and higher prevented pregnancy in all treated animals (Table 1). It was partially effective at the dose of $5 \mathrm{\mu g} \mathrm{kg}^{-1}$ day ${ }^{-1}$, that is, $67 \%$ of treated animals were infertile, and not effective at the lowest dose of $2.5 \mu \mathrm{g} \mathrm{kg}^{-1}$ day $^{-1}$.

Serum concentrations of progesterone were significantly reduced in animals treated with cabergoline at doses of $5 \mu \mathrm{g}$ $\mathrm{kg}^{-1}$ day ${ }^{-1}$ and higher (Table 2 and Fig. I). The mean serum concentrations of oestradiol in cabergoline-treated animals remained unchanged (Fig. 2).

Serum prolactin was determined in pregnant rats treated with cabergoline at the effective dose of $10 \mu \mathrm{g} \mathrm{kg}^{-1}$ day ${ }^{-1}$ on days 1,2 , and 3 of pregnancy. The serum concentrations of prolactin before treatment and on days 4 and 6 of pregnancy were $16.0 \pm 4.3,1.71 \pm 0.62$ and $31.0 \pm 12.0 \mathrm{ng} \mathrm{ml}^{-1}$, respectively. Serum concentrations of prolactin were markedly reduced on day 4 of pregnancy or $24 \mathrm{~h}$ after the last dose of the drug, then rebounded to exceed pretreatment values by day or $72 \mathrm{~h}$ after the last dose. The effective dose of cabergoline to reduce serum concentrations of prolactin on day 8 of pregnancy was determined (Table 3). Doses of $20 \mu \mathrm{g} \mathrm{kg}^{-1} \mathrm{day}^{-1}$ or higher significantly reduced serum prolactin concentration.

Examination under the microscope of histological sections of ovaries obtained from rats treated with cabergoline at doses of 
Table 2. Serum concentrations of progesterone in pregnant rats treated with cabergoline

\begin{tabular}{lcc}
\hline $\begin{array}{l}\text { Cabergoline }^{a} \\
\left(\mu \mathrm{kg}^{-1} \text { day }^{-1}\right)\end{array}$ & $\begin{array}{c}\text { Number } \\
\text { of rats }\end{array}$ & $\begin{array}{c}\text { Serum } \\
\text { progesterone } \\
\left(\mathrm{ng} \mathrm{m} l^{-1}\right)^{6}\end{array}$ \\
\hline 0 & 9 & $48.6 \pm 6.3$ \\
2.5 & 10 & $43.3 \pm 4.4$ \\
5 & 9 & $21.2 \pm 2.2^{*}$ \\
10 & 9 & $29.2 \pm 2.1^{*}$ \\
20 & 6 & $15.1 \pm 1.6^{*}$ \\
30 & 10 & $13.0 \pm 4.3^{*}$ \\
60 & 9 & $4.8 \pm 0.6^{* *}$ \\
\hline
\end{tabular}

Values are means $\pm \mathrm{SLM}$.

${ }^{2}$ Cabergoline was administered s.c. on days 1, 2 and 3 of pregnancy

berum progesterone determined on day 8 of pregnancy.

${ }^{*} P<0.01 ;{ }^{*} P<0.001$, compared with untreated value.

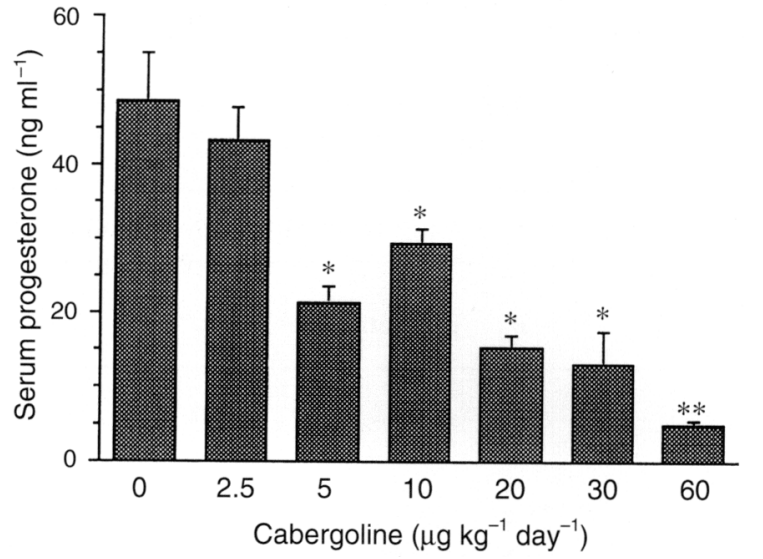

Fig. 1. Serum concentrations of progesterone in pregnant rats treated with various doses of cabergoline. Cabergoline was administered s.c. on days 1, 2 and 3 of pregnancy. Serum progesterone was determined on day 8 of pregnancy. Mean \pm SEM; $n=6-10$ rats. ${ }^{*} P<0.01$; $* * P<0.001$, compared with untreated value.

2.5 to $20 \mu \mathrm{g} \mathrm{kg}^{-1}$ day $^{-1}$ on days, 1, 2 and 3 of pregnancy revealed no morphological alterations to the corpora lutea of pregnancy (data not shown).

\section{Termination of pregnancy}

Cabergoline at doses of 30,60 and $100 \mu \mathrm{gg}^{-1} \mathrm{day}^{-1}$ administered s.c. on days 7,8 and 9 of pregnancy terminated pregnancy in all treated animals (Table 4). The drug was partially effective at doses of 10 and $20 \mathrm{\mu g} \mathrm{kg}^{-1}$ day $^{-1}$ and was not effective at doses of 2 and $5 \mu \mathrm{g} \mathrm{kg}^{-1}$ day ${ }^{-1}$.

Serum concentrations of progesterone were determined on days 7,12 and 16 of pregnancy (Table 5). In animals treated with non-effective doses ( 2 and $5 \mu \mathrm{g} \mathrm{kg}^{-1}$ day $^{-1}$ ) of cabergoline, the mean serum concentrations of progesterone on days 12 and 16 of pregnancy remained unchanged (Table 5). Treatment with partially effective doses of cabergoline (10 and $20 \mu \mathrm{gg}^{-1}$ day $^{-1}$ ) reduced serum progesterone significantly on days 12 and 16 of pregnancy. When rats treated with $20 \mu \mathrm{g}$

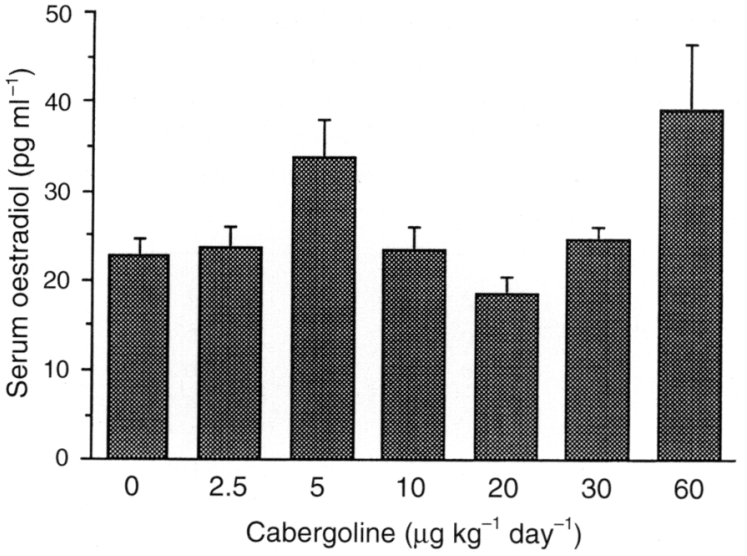

Fig. 2. Serum concentrations of oestradiol in pregnant rats treated with various doses of cabergoline. Cabergoline was administered s.c. on days 1, 2 and 3 of pregnancy. Serum concentrations of oestradiol were determined on day 8 of pregnancy. Mean \pm SEM; $n=6-10$ rats.

Table 3. Mean serum concentrations of prolactin in pregnant female rats treated with cabergoline

\begin{tabular}{lcc}
\hline $\begin{array}{l}\text { Cabergoline } \\
\left(\mu \mathrm{g} \mathrm{kg}^{-1} \text { day }^{-1}\right)\end{array}$ & $\begin{array}{c}\text { Number } \\
\text { of animals }\end{array}$ & $\begin{array}{c}\text { Serum rPRL } \\
\left(\mathrm{ng} \mathrm{ml}^{-1}\right)\end{array}$ \\
\hline 0 & 8 & $53.5 \pm 15.4$ \\
2.5 & 10 & $69.4 \pm 21.4$ \\
5 & 9 & $63.8 \pm 17.2$ \\
10 & 9 & $67.7 \pm 12.7$ \\
20 & 6 & $37.8 \pm 10.5^{*}$ \\
30 & 10 & $18.4 \pm 8.9^{* *}$ \\
60 & 9 & $2.2 \pm 0.7^{* *}$ \\
\hline
\end{tabular}

Values are means \pm SE:M.

${ }^{a}$ Cabergoline was administered s.c. on days I, 2 and 3 of pregnancy.

'Serum rPRL (prolactin) was determined on day 8 of pregnancy.

${ }^{*} P<0.01 ;{ }^{*} P<0.001$, compared with untreated values.

cabergoline $\mathrm{kg}^{-1}$ day ${ }^{-1}$ were divided into pregnant and non-pregnant groups (Fig. 3), the serum concentrations of progesterone were significantly lower in the non-pregnant group. In animals treated with doses that were 100\% effective $\left(30,60\right.$ and $\left.100 \mu \mathrm{g} \mathrm{kg}^{-1} \mathrm{day}^{-1}\right)$, the serum concentrations of progesterone on days 12 and 16 of pregnancy were significantly lower (Table 5).

Serum concentrations of oestradiol on days 7,12 and 16 of pregnancy were determined in control and cabergoline-treated animals (Table 6). Serum concentrations of oestradiol on days 7 and 12 of cabergoline-treated pregnant animals were similar to untreated values. However, in animals treated with effective doses of 30,60 and $100 \mathrm{\mu g} \mathrm{kg}^{-1}$ day $^{-1}$, the mean serum concentrations of oestradiol on day 16 of pregnancy were significantly lower than those of untreated pregnant rats and those treated with non-effective doses. The increment increase in serum concentrations of oestradiol noted on day 16 of pregnancy in the untreated group compared with the concentrations observed on days 7 and 12 is due to the placental production of this steroid. This placenta source of oestradiol was eliminated upon termination of pregnancy by day 16 . 
Table 4. Effect of various doses of cabergoline in terminating pregnancy in rats

\begin{tabular}{|c|c|c|c|c|}
\hline $\begin{array}{l}\text { Cabergoline" } \\
\left(\mu \mathrm{g} \mathrm{kg}^{-1} \text { day }^{-1}\right)\end{array}$ & $\begin{array}{c}\text { Treated } \\
\text { rats } \\
(n)\end{array}$ & $\begin{array}{l}\text { Without } \\
\text { embryos } \\
(n)\end{array}$ & $\begin{array}{c}\text { With } \\
\text { embryo } \\
(n)\end{array}$ & $\begin{array}{c}\text { Termination } \\
\text { of pregnancy } \\
(\%)\end{array}$ \\
\hline
\end{tabular}

\begin{tabular}{rrrrc}
\hline 0 & 12 & 0 & 12 & 0 \\
2 & 6 & 0 & 6 & 0 \\
5 & 6 & 0 & 6 & 0 \\
10 & 7 & 3 & 4 & 42.9 \\
20 & 8 & 4 & 4 & 50.0 \\
30 & 7 & 7 & 0 & 100 \\
60 & 10 & 10 & 0 & 100 \\
100 & 10 & 10 & 0 & 100 \\
\hline
\end{tabular}

"Cabergoline was administered s.c. on days 7,8 and 9 of pregnancy. Animals were killed on day 16 of pregnancy and uterus examined for embryos.

Table 5. Mean serum progesterone concentrations in cabergoline-treated pregnant rats

\begin{tabular}{|c|c|c|c|c|}
\hline \multirow[b]{2}{*}{$\begin{array}{l}\text { Cabergoline }^{\mathrm{a}} \\
\left(\mu \mathrm{g} \mathrm{kg}{ }^{-1} \text { day }^{-1}\right)\end{array}$} & \multirow[b]{2}{*}{$n$} & \multicolumn{3}{|c|}{ Serum progesterone $\left(\mathrm{ng} \mathrm{ml}^{-1, \mathrm{~b}}\right.$} \\
\hline & & $\begin{array}{c}\text { Day } 7 \\
\text { (pretreatment) }\end{array}$ & Day 12 & Day 16 \\
\hline 0 & 12 & $61.8 \pm 5.5$ & $65.9 \pm 5.9$ & $70.7 \pm 11.0$ \\
\hline 2 & 7 & $59.6 \pm 9.4$ & $62.2 \pm 12.1$ & $79.5 \pm 22.9$ \\
\hline 5 & 6 & $47.2 \pm 3.0$ & $60.2 \pm 4.2$ & $65.0 \pm 13.5$ \\
\hline 10 & 7 & $52.4 \pm 9.9$ & $35.0 \pm 9.4^{*}$ & $30.5 \pm 9.6^{*}$ \\
\hline 20 & 8 & $52.7 \pm 4.7$ & $35.6 \pm 11.0^{*}$ & $33.6 \pm 13.6^{*}$ \\
\hline 30 & 6 & $65.2 \pm 12.2$ & $16.9 \pm 4.1^{* *}$ & $8.0 \pm 1.6^{* *}$ \\
\hline 60 & 7 & $71.6 \pm 7.4$ & $22.2 \pm 14.8^{* *}$ & $15.5 \pm 9.1^{* *}$ \\
\hline 100 & 7 & $62.9 \pm 7.3$ & $8.6 \pm 2.1^{* *}$ & $9.3 \pm 2.5^{* *}$ \\
\hline
\end{tabular}

Values are means \pm SEM.

"Cabergoline was administered on days 7,8 and 9 of pregnancy.

"Serum progesterone was determined on days 7,12 and 16 of pregnancy.

$* P<0.01 ; * *<<0.001$, compared with untreated values.

\section{Discussion}

The present results show that cabergoline is effective in preventing implantation and terminating pregnancy in rats. Cabergoline is a dopamine agonist that blocks the release of prolactin from the pituitary (Di Salle et al., 1983a, b). Since prolactin stimulates the production of progesterone by the ovary, a reduction in prolactin will result in a decrease of serum concentrations of progesterone, thereby interfering with the implantation of blastocysts and maintenance of the developing embryos (Psychoyos, 1967). The capacity of dopamine agonists to interfere with fertility and reproduction in rats was also demonstrated with terguride, a derivative of the ergot alkaloid, which lowers serum prolactin in rats and dogs (Mizokawa et al., 1993), inhibits implantation of blastocyts and interferes with the development of embryos in rats (Kodama et al., 1993a, b, c).

In cabergoline-treated animals, the histological architecture of the corpora lutea of pregnancy appeared normal in the presence of low serum prolactin and reduced progesterone

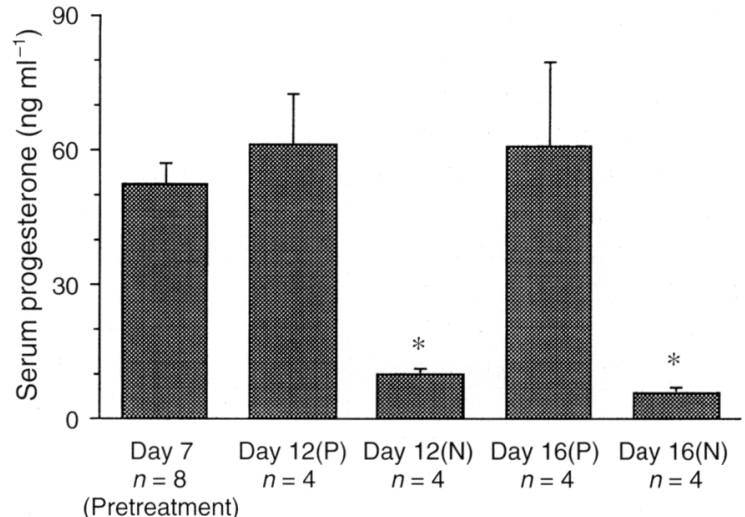

Fig. 3. Serum concentrations of progesterone in cabergoline-treated pregnant rats. A partially effective dose of cabergoline $\left(20 \mu \mathrm{g} \mathrm{kg}^{-1}\right.$ day $^{-1}$ ) was administered on days 7,8 and 9 of pregnancy. The animals were divided into nonpregnant and pregnant groups. Serum concentrations of progesterone were determined on days 7 (pretreatment), 12 and 16 of pregnancy. Mean \pm SEM. ${ }^{*} P<0.001$, non-pregnant $(N)$ group compared with pregnant $(\mathrm{P})$ group.

Table 6. Serum concentrations of oestradiol in pregnant rats treated with cabergoline

\begin{tabular}{lrllll}
\hline & \multicolumn{4}{c}{ Serum oestradiol $\left(\mathrm{pg} \mathrm{ml}{ }^{-1}\right)^{\mathrm{b}}$} \\
\cline { 2 - 5 } $\begin{array}{l}\text { Cabergoline } \\
\left(\mu \mathrm{g} \mathrm{kg}^{-1} \text { day }^{-1}\right)\end{array}$ & $n$ & $\begin{array}{c}\text { Day } 7 \\
\text { (pretreatment) }\end{array}$ & Day 12 & Day 16 \\
\hline & 11 & $25.4 \pm 3.6$ & $21.2 \pm 1.0$ & $39.2 \pm 4.1$ \\
0 & 7 & $24.0 \pm 2.8$ & $20.3 \pm 3.0$ & $36.2 \pm 3.5$ \\
2 & 6 & $22.0 \pm 3.1$ & $22.7 \pm 5.4$ & $38.5 \pm 9.1$ \\
5 & 9 & $25.1 \pm 4.5$ & $18.6 \pm 0.9$ & $29.5 \pm 1.7$ \\
10 & 8 & $13.4 \pm 1.9$ & $20.5 \pm 1.7$ & $24.2 \pm 4.3^{*}$ \\
20 & 5 & $13.2 \pm 2.0$ & $24.5 \pm 5.1$ & $23.8 \pm 4.7^{*}$ \\
30 & 7 & $14.9 \pm 2.3$ & $25.7 \pm 4.3$ & $23.4 \pm 3.9^{*}$ \\
60 & 5 & $15.3 \pm 3.3$ & $29.7 \pm 10.0$ & $24.1 \pm 3.5^{*}$ \\
100 & & & & & \\
\hline
\end{tabular}

Values are means \pm SEM.

${ }^{a}$ Cabergoline was administered on days 7,8 and 9 of pregnancy.

'Serum oestradial determined on days 7,12 and 16 of pregnancy.

$* P<0.01$, compared with untreated values.

production. This experimental condition is similar to androgensterilized rats (Hahn and McGuire, 1978) in which the oestrous cycle is characterized by constant oestrus; however, injection of $\mathrm{GnRH}$ can induce ovulation. When these animals are mated, viable embryos are produced, although the pregnancy is not maintained and the embryos are aborted due to a deficiency of progesterone. However, when exogenous progesterone or prolactin is administered to these animals, implantation will be induced and the embryos will develop normally.

The blockage of prolactin production by cabergoline at a dose of $10 \mu \mathrm{g} \mathrm{kg}^{-1}$ day ${ }^{-1}$ lasts for about $24 \mathrm{~h}$. The effect of the block is longer $(120 \mathrm{~h})$ at higher doses $\left(20-60 \mu \mathrm{g} \mathrm{kg}^{-1}\right.$ day $^{-1}$ ) of the drug. However, the reduction in serum concentrations of progesterone may persist for about 7 days after the last dose. These results suggest that cabergoline may be used as a post-coital medication by administering it as a single dose 
on days 1-3 of pregnancy which would effectively interfere with the implantation of blastocysts.

The serum concentrations of oestradiol on day 7 of pregnancy (pretreatment) showed marked variation which stabilized by day 12 of pregnancy. The concentrations were similar among the three groups: untreated rats, rats treated with non-effective and effective doses. These findings suggest that oestradiol is primarily produced by the ovary at this time and its production is not affected by treatment with cabergoline. However, oestradiol concentrations were higher on day 16 of pregnancy compared with those on day 12 in untreated pregnant rats and in those treated with a non-effective dose. These findings suggest that the placenta has started to produce oestrogen by day 16 of pregnancy. Cabergoline administered on days 7,8 and 9 of pregnancy does not influence serum oestradiol concentrations on day 12 of pregnancy when the ovary was the source. Serum concentrations of oestradiol were significantly reduced, however, on day 16 of pregnancy in rats treated with effective doses of cabergoline $\left(30 \mu \mathrm{g} \mathrm{kg}^{-1}\right.$ day ${ }^{-1}$ or higher) compared with untreated animals or with the pretreatment concentrations (day 7 of pregnancy), showing that the placenta was eliminated as a source of oestradiol by this day. In conclusion, cabergoline effectively prevents and terminates pregnancy in rats by blocking production or release of prolactin, thereby reducing progesterone biosynthesis, inhibiting implantation of blastocysts and interfering with the development of embryos.

This work was undertaken as part of the Contraceptive Development Program of the International Committee for Contraception of the Population Council. Financial support was provided by the Fred $\mathrm{H}$. Bixby Foundation, The Educational Foundation of America, The Charitable Trust of Mrs Abby R. Mauze, The Edward John Noble Foundation, The Playboy Foundation, and The Swedish International Development Authority (Government of Sweden).

\section{References}

Avrech OM, Golan A, Weintraub Z, Bukovsky l and Caspi E (1991) Mifepristone (RU 486) alone or in combination with prostaglandin analogue for termination of pregnancy: a review Fertility and Sterility 56 385-393

Di Salle E, Ornati G and Briatico G (1983a) FCE 21336, a new ergoline derivative with a potent and long-acting lowering effect on prolactin secretion in rats Journal of Endocrinological Investigation 5 (Supplement 1) 45

Di Salle E, Ornati G, Guidici D and Briatico G (1983b) Prolactin lowering effect of a new ergoline derivative, FCE 21336, in the rat: a comparison with bromocryptine Acta Endocrinologica 103 (Supplement 256) 265
Fasoli M, Parazzini F, Cechetti G and LaVecchai C (1989) Postcoital contraception: an overview of published studies Contraception 39 459-468

Ferraro F, Nisoli LGC, Salvo R, Maffe G and Jöckle W (1995) Periodic use of cabergoline, a prolactin inhibitor, for control of reproductive success in rats - work in progress Theriogenology 44 I-7

Hahn DW and McGuire JL (1978) The androgen sterilized rat: ovulation and implantation by luteinizing hormone-releasing hormone Endocrinology 102 1741-1747

Jöckle W and Jöckle $M$ (1993) Reproduction in a feral cat population and its control with a prolactin inhibitor (cabergoline) Joumal of Reproduction and Fertility Supplement 47 419-424

Kodama N, Kato K, Urabe K and Gayeyama A (1993a) Toxicity study of terguride: fertility study in female rats Japanese Pharmacology and Therapeutics $2157-63$

Kodama N, Kato K, Urabe K and Gayeyama A (1993b) Toxicity study of terguride: preimplantation reproduction study in female rats Japanese Pharmacology and Therapeutics 21 65-70

Kodama N, Kato K, Urabe K and Gayeyama A (1993c) Toxicity study of terguride: prenatal and postnatal study in rats Japanese Pharmacology and Therpeutics 21 93-106

Mizokawa T, Akai T, Nakada Y, Yamaguchi M, Nakagawa H, Hasan S, Rettig KJ and Wachtel $\mathbf{H}$ (1993) Terguride as a new anti-hyperprolactinemic agent: characterization in rats and dogs in comparison with bromocriptine Japanese Journal of Pharmacology 63 269-278

Neil JD and Reichert LE, Jr (1971) Development of a radioimmunoassay for rat prolactin and evaluation of the NIAMD rat prolactin radioimmunoassay Endocrinology $\mathbf{8 8} 548-555$

Onclin K, Silva LDM, Donnay F and Verstegen JP (1993) Luteotrophic action of prolactin in dogs and effects of a dopamine agonist, cabergoline Journal of Reproduction and Fertility Supplement $47403-409$

Peplow PV (1994) RU 486 combine with PGE $_{1}$ analog in voluntary termination of early pregnancy - a comparison of recent findings with gemeprost or misoprostol Contraception 50 69-75

Post K, Evans LE and Jöckle W (1988) Effect of prolactin suppression with cabergoline in the pregnancy of the bitch Theriogenology 29 1233-1243

Psychoyos A (1967) The hormonal interplay controlling egg-implantation in the rat. In Advances in Reproductive Physiology Vol. Il pp 257-277 Ed. A McLaren Academic Press, London

Rains CP, Bryson HM and Fitton A (1995) Cabergoline: a review of its pharmacological properties and therapeutic potential in the treatment of hyperprolactinaemia and inhibition of lactation Drugs 49 255-279

Shanghai Clinical Research Coordinating Group on Antifertility Table No 53 (1977) Clinical observation of the home leave antifertility tablet No. 53. Chinese Medical Journal 10 618-620

Silvestre AL, Dubois C, Renault M, Rezvani Y, Baulieu EE and Ulmann A (1990) Voluntary interruption of pregnancy with mifepristone (RU 486) and a prostaglandin analogue New England Journal of Medicine 322 645-648

Spitz IM and Bardin CW (1993) Mifepristone (RU 486) - a modulator of progestin and glucocorticoid action New England Journal of Medicine 329 $404-412$

Verstegen JP, Onclin K, Silva LDM and Donnay F (1993) Abortion induction in the cat using prostaglandin $\mathrm{F}_{2 u}$ and a new anti-prolactinic agent, cabergoline. Journal of Reproduction and Fertility Supplement 47 411-417

Webster J, Piscitelli G, Polli A, Ferrari CI, Ismail I and Scanlon MF (1994) A comparison of cabergoline and bromocriptine in the treatment of hyperprolactinemia amenorrhea New England Journal of Medicine 331 904-909 